\title{
Index of Atmospheric Purity reflects the ecological conditions better than the environmental pollution in the Carpathian forests
}

\author{
Magdalena TANONA* (D https://orcid.org/oooo-ooo1-9286-3679; Me-mail: magdalena.tanona@gmail.com \\ Paweł CZARNOTA iDhttps://orcid.org/oooo-0oo2-1515-6214; e-mail: pczarnota1@gmail.com \\ ${ }^{*}$ Corresponding author \\ Department of Ecology and Environmental Protection, University of Rzeszów, Zelwerowicza 4 Street, 35-6o1 Rzeszów, \\ Poland
}

Citation: Tanona M, Czarnota P (2020) Index of Atmospheric Purity reflects the ecological conditions better than the environmental pollution in the Carpathian forests. Journal of Mountain Science 17(11). https://doi.org/10.1007/s11629-0206266-1

(C) The Author(s) 2020.

\begin{abstract}
The Index of Atmospheric Purity (IAP) is a popular tool used for the assessment of air quality in polluted urban areas, on the basis of phytosociological data of epiphytic lichen communities. We hypothesized that this indicator could also be used in less polluted forest areas to determine the quality of ecological conditions for lichens. The aim of the present study was to verify the use of IAP method in the assessment of environmental pollution, and alternatively for the assessment of general ecological conditions in protected mountain forests of Gorce National Park (Polish Western Carpathians) based on the epiphytic lichen biota associated with Picea abies. The spatial distribution of IAP values on monitored sites in GNP was compared with: 1) spatial distribution of accumulated sulfur, nitrogen, selected heavy metals, and total heavy metals in Hypogymnia physodes thalli in 1993 and 2018 (30 sites), 2) mean ecological indicator values characterizing species requirements for light (L), substrate reaction (R) and nutrients (N), in 1993, 2013 and 2018 (33 sites). Generalized linear model and redundancy analysis were performed for disclosing most influencing factors affecting lichen communities. The study revealed a few negligible relationships between IAP values and accumulation of such elements as $\mathrm{Ni}, \mathrm{Mn}$, $\mathrm{Cd}$, and $\mathrm{Cr}$ in both monitoring periods.
\end{abstract}

Received: 14-Jun-2020

Revised: 04-Sep-2020

Accepted: 29-Sep-2020
Simultaneously, IAP can be useful for the identification of forest areas with a high degree of naturalness.

Keywords: Biomonitoring; Lichens; Forest ecology; Norway spruce; Ecological indices; Environmental pollution

\section{Introduction}

Due to water and toxic elements absorption directly from the atmosphere, lichens are regarded as excellent bioindicators of air pollution (Gries 2008; Sujetovienè 2015; Will-Wolf et al. 2015). Analytical techniques used for air quality assessment as well as regular monitoring of urban areas allow for the confrontation of the results from biological monitoring and the instrumental measurements of air pollution. Results of studies conducted in conurbations or near point sources of pollution usually confirm the legitimacy of using lichens in the bioindication of air pollution in these areas, for example those caused by sulfur dioxide (Białońska and Dayan 2005; Orlova et al. 2015; Mateos and González 2016), nitrogen oxides (GaioOliveira et al. 2005; Tretiach et al. 2007; Mateos and González 2016) and heavy metals (Kularatne 
and De Freitas 2013; Parzych et al. 2016). The accumulation of toxic elements in lichen thalli is negatively correlated with an increasing distance from the main sources of pollution (Salemaa et al. 2004; Attanayaka and Wijeyaratne 2013). This correlation is clearly seen in the urban landscape, as air pollution is usually the main ecological factor determining the composition of lichen biota (Seaward 2015). For areas characterised by higher heterogeneity or degree of naturalness, the interpretation of an effect of urban and industrial pollutants on the environment is more complicated (Poikolainen et al. 2000; Gombert et al. 2004; Giordani 2007; Agnan et al. 2017). This is caused by the synergistic or antagonistic effect of many ecological factors (e.g. climate, topography, habitat, anthropogenic impact) determining the sensitivity of individual lichen species to the same concentrations of harmful substances (e.g. Van Dobben et al. 2001; Brunialti et al. 2010; Liu et al. 2016).

The Index of Atmospheric Purity (IAP) relies on phytosociological indicators and is a popular tool used for the assessment of air quality in urban areas. This method assumes that the growth of epiphytic lichens in urban areas is primarily determined by air quality. The basic formula developed by LeBlanc and De Sloover (1970) has been modified throughout the years. For example, Kricke and Loppi (2002) compared twenty distributions based on various versions of the IAP with the results of instrumental measurements conducted in the late 1980's (Ammann et al. 1987). The highest coefficient of determination $\left(R^{2}=0.97\right.$, $p<0.05$ ) was obtained by applying the formula based on the sum of frequencies of species found on a site. This variant of IAP was later used by Gombert et al. (2004) while conducting research in the urban area of Grenoble, France. Researchers concluded that the obtained values of IAP were more accurate when considered as a degree of anthropogenic transformation of the environment than as a mean annual concentration of air pollutants. Sites with high IAP values were dominated mainly by species without any strong preference for specific $\mathrm{pH}$ of the bark and trophic conditions, while nitrophilous and acidophilous species prevailed on sites characterised by low IAP values. Gombert et al. (2004) found no relationships between the distributions of the modified IAP values and mean annual concentrations of both sulfur and nitrogen oxides in the air as well as the distance from the main sources of pollution. This means that the use of the bioindication method based on the IAP criteria has to be adapted to local conditions and lichen biota and requires regular validation regardless of the degree of urbanisation. Despite the IAP is designed to describe specifically the urban areas, some authors have put effort into explaining the IAP values obtained from air-polluted forests (e.g. Poikolainen et al. 2000; Jeran et al. 2002; Jayalal et al. 2017), which can be considered wrong.

The doubts surrounding the IAP method application in air quality assessment does not preclude its use in bioindication of the forest environment, i.e. the quality assessment of ecological conditions for lichens. Conclusions resulting from this kind of approach would have to be general, as in more heterogeneous ecosystems the growth of lichens is affected by a more diverse range of limiting ecological factors, such as: insolation, relative humidity, competition for space, the age and species of trees, etc. (e.g. Gibson et al. 2013). With regard to mountain forests, an inference is even more difficult, as demonstrated studies carried out in Carpathians by Bytnerowicz et al. (2002) have shown that the relationship between pollution and environmental factors can change on a daily, seasonal and multiannual scale. For this reason, a particularly long-term research on the application of the IAP method in mountain forests is recommended to identify these environmental factors that determine the dynamics of lichen communities.

The aim of the present study was to evaluate the suitability of the IAP, as originally proposed by LeBlanc and De Sloover (1970), as follows: 1) as a bioindicator-based assessment of pollution in large areas of natural forests in the Western Carpathians caused by toxic elements and to compare the obtained results with the concentrations of these elements instrumentally measured in Hypogymnia physodes thalli; 2) as an alternative use in an assessment of general ecological conditions in the dynamically changing forest ecosystems of the Carpathians. The following working hypotheses were adopted: 1) there is a consistent lack of significant ( $\alpha=0.05)$ relationships between IAP values and the concentrations of elements 
measured separately in two study years -1993 and 2018; 2) IAP values for study areas correspond with ecological indicator values (Wirth 2010) in each of the three study years: 1993, 2013 and 2018.

\section{Study Area and Methods}

\subsection{Study area}

The study was conducted in Gorce National Park $\left(49^{\circ} 37^{\prime} 18.802^{\prime \prime}-49^{\circ} 30^{\prime} 34.218^{\prime \prime} \mathrm{N}\right.$ and $\left.20^{\circ} 01^{\prime} 20.867^{\prime \prime}-20^{\circ} 15^{\prime} 10.850^{\prime \prime} \mathrm{E}\right)$ located in the Gorce range in the Polish part of the Western Carpathians. The Gorce ranges are flysch, mediumheight mountains with the highest peak, Turbacz, at $1311 \mathrm{~m}$ a.s.l. (Cieszkowski 2006).

Gorce National Park was established mainly to protect remnants of old-growth Carpathian forest with preserved patches representing different variants of the lower belt beech forest Dentario glandulosae-Fagetum and fir-spruce forest AbietiPiceetum montanum as well as subalpine spruce forest Plagiothecio-Piceetum (Loch and Armatys 2008). The subalpine zone ranges above ca. 1050 $\mathrm{m}$ a.s.l. Fragments of primeval forest cover only $1.26 \%$ of the total forested area of GNP, which is 6313.6 ha. Natural forests and managed forests of a semi-natural character (with species composition consistent with the habitat, mainly formed by natural regeneration) account for 90\% of this area (as of 1997; Loch and Armatys 2008).

The climate of Gorce range is mainly influenced by montane conditions. The diversified topography defines distinct differences in temperature, insolation, humidity, wind speed and the persistence of snow cover between sites that are not located far apart as well as for significant local fluctuations in these parameters. The mean annual temperature in the foothills is $6^{\circ} \mathrm{C}$ and drops to $3^{\circ} \mathrm{C}$ on the top of Turbacz Mt. The total annual precipitation ranges between $800-1200 \mathrm{~mm}$ and varies depending on the altitude above sea level. Most of the pollutants are carried together with the wind, usually blowing from the $\mathrm{N}$ and $\mathrm{NW}$ directions, and originate in the distant industrial region of Upper Silesia and Kraków located about 60 to $100 \mathrm{~km}$ northwest and north of the Gorce range. The wind direction is also locally determined by the course of river valleys. There are also periodic foehn winds that reach high speeds causing numerous windthrows in large areas, accelerating decomposition of spruce stands (Miczyński 2015).

\subsection{Field data collection}

The study was conducted in three years: 1993 , 2013 and 2018 on 39 circular plots selected from a net of $400 \mathrm{~m} \times 400 \mathrm{~m}$ plots regularly distributed within the whole area of the national park. The 13 plots were established in the subalpine mountain belt covered with Plagiothecio-Piceetum community and the remaining 26 were located in both lower and transition mountain belts within mixed spruce-fir-beech forests (Dentario glandulosae-Fagetum community) with dominating share of Picea abies in 1993. In 1993 ten spruces growing closest to the centre of each plot were selected and a survey of epiphytic lichens on a patch of bark was conducted from the ground level up to $2 \mathrm{~m}$ above the ground, around the trunk. The rate of coverage for each recorded lichen species on each patch was also estimated according to the following ranks: $+:<1 \% ; 1: 1 \%-5 \%$; 2 : $6 \%-$ 25\%; 3: $26 \%-50 \%$; 4: 51\%-75\%; 5: $76 \%-100 \%$. Because of the dynamic dieback of spruce forests within the Gorce range, mainly caused by the activity of European spruce bark beetle (Ips typographus L.), final analyses and interpretations were carried out using phytosociological data collected on 33 plots from 186 live spruces (out of 370 trees analysed in the first stage of research). Full species list with the sum of cover coefficients is available in Appendix 1. In the years 1993 and 2018 at each plot (wherever possible) thalli of Hypogymnia physodes were collected from the branches of standing trees or recently fallen branches or crowns of windthrowed trees (branches with needles still green, not in contact with the soil) and analysed for the concentrations of accumulated sulfur and heavy metals: $\mathrm{Cr}, \mathrm{Mn}$, $\mathrm{Cu}, \mathrm{Zn}, \mathrm{Ni}, \mathrm{Cd}$ and $\mathrm{Pb}$. In 2018, in addition to the previous set, concentration of nitrogen was also measured. The lack of suitable substrate in the immediate vicinity occurred in 3 of 33 sites in 2018 . Eventually, the comparative analysis of the IAP values and the concentrations of accumulated elements were carried out for the remaining 30 sites. 


\subsection{Laboratory work}

Lichen specimens, for which the identification of species based on morphological features was impossible in situ, were further investigated in a laboratory. The specimens were identified using standard microscopic techniques including simple spot test reactions with $\mathrm{KOH}, \mathrm{CaOCl}$ and an alcohol solution of paraphenyldiamine (PPD). The nomenclature of lichen taxa followed Fattynowicz and Kossowska (2018). Taxa were identified to the species level, except for sterile representatives of the genus Lepraria, which share would have been difficult to estimate because of morphological similarity. The dominant epiphytic representative of the genus in this study area was Lepraria jackii, but also L. elobata and L. finkii were frequent (Czarnota and Kukwa 2001). Currently recognized species in Cladonia pyxidata, Micarea micrococca and $M$. prasina complexes were also not precisely identified due to the unclear nomenclature or taxonomic status of cryptic species within these groups at the beginning of the study in 1993 (Wirth 1995; Smith et al. 2009). Finally, the taxa were treated as species sensu lato.

In 1993 the concentrations of heavy metals in Hypogymnia physodes thalli samples (ca. $1.2 \mathrm{~g}$ of dry weight) were analysed using Atomic Absorption Spectrometry (AAS) after preceding mineralization in $65 \%$ nitric acid. The measurement uncertainty was estimated in accordance to the upon standard procedure based on 7 replicates from one randomly chosen sample from site no. 21086. The relative standard deviation based on the series of measurements was: $3.7 \%$ for $\mathrm{Cr}, 1.59 \%$ for $\mathrm{Mn}, 2.83 \%$ for $\mathrm{Cu}, 0.64 \%$ for $\mathrm{Zn}, 32.62 \%$ for $\mathrm{Ni}, 5.03 \%$ for $\mathrm{Cd}$ and $5.06 \%$ for $\mathrm{Pb}$. The concentration of sulfur was determined by nephelometry (see Czarnota 1995).

Concentrations of heavy metals in $H$. physodes thalli collected in 2018 were also analysed using methods described above. The averaged absorbance values of three technical repeats for each element were used to determine the concentrations, although a qualitative analysis of sulfur and nitrogen was performed using the CHNOS instrumental method. Samples of a homogeneous mixture of manually cleaned thalli collected from each site, weighing approximately $20 \mathrm{mg}$, were placed in tin foil containers and processed with the vario EL cube elemental analyser according to the procedure developed by Namieśnik and Jamrógiewicz (1998). Cleaned gaseous combustion products undergo separation in absorption columns into individual components (nitrogen, carbon dioxide, sulfur dioxide, water vapour) and are detected by the measuring cell of the TCD thermal conductivity detector. Each sample was divided into three subsamples which were measured thrice in order to obtain the value of standard uncertainty for each site. Both methods were calibrated and validated on the basis of certified reference material (SRM 1547 peach leaves). Recovery rates of $\mathrm{N}$ and $\mathrm{S}$ in the elemental analysis were $94 \%$ and $82 \%$, respectively. In the AAS method, the recovery of $\mathrm{Zn}$ and $\mathrm{Cu}$ exceeded 90\%, while for $\mathrm{Mn}, \mathrm{Pb}, \mathrm{Cd}, \mathrm{Ni}$ and $\mathrm{Cr}>80 \%$ recovery was obtained.

\subsection{Data processing and analysis}

\subsubsection{Index of Atmospheric Purity}

The phytosociological data from each study site were used for the calculation of the Index of Atmospheric Purity (IAP) in accordance to the original methodology of LeBlanc and De Sloover (1970) by using the following formula:

$$
\mathrm{IAP}=\frac{1}{10} \sum_{1}^{n} Q \times f
$$

where, $n$ is the number of species; $f$ is the frequency-coverage score of each species calculated by compiling the constancy class of occurrence and the rate of cover in the analysed plot of sampled trunks (see Table 1); $Q$ is ecological sensitivity

Table 1 The assessment of $f$ coefficient used in IAP validation; criteria for the constancy occurrence class of species: I: 20\%; II: 21\%-40\%; III: 41\%-60\%; IV: 61\%$80 \%$; V: $81 \%-100 \%$ (the criteria for determining the $f$ coefficient have been specified here by authors).

\begin{tabular}{|l|l|l|}
$\begin{array}{l}\text { Index of patch } \\
\text { cover (\%) }\end{array}$ & $\begin{array}{l}\text { Constancy } \\
\text { class }\end{array}$ & $f$ coefficient value \\
\hline$<50$ & I & 1 \\
\hline$<2.5$ & II & 1 \\
\hline$>2.5$ & II & 2 \\
$<5$ & III & 2 \\
\hline$>5$ & III & 3 \\
\hline$<2.5$ & IV & 2 \\
\hline $2.5-25$ & IV & 3 \\
\hline$>25$ & IV & 4 \\
\hline$<2.5$ & V & 3 \\
\hline $2.5-25$ & V & 4 \\
\hline$>25$ & V & 5 \\
\hline
\end{tabular}


index of each species calculated based on the mean number of species coexisting on a site with given species.

\subsubsection{Ecological indicator values}

Each of the epiphytic lichen species was assigned an ecological indicator value proposed by Wirth (2010), describing habitat requirements on the 1-9 scale with relation to light (L), nutrients (N) and substrate reaction (R). The higher scale values correspond with increased either light intensity, concentration of nutrients or $\mathrm{pH}$ of the habitat. A small number of lichen species that have not been previously characterised by Wirth were described using a similar 5-degree scale proposed by Fabiszewski and Szczepańska (2010) developed for species common in Poland. Note that the value ' 1 ' on this scale refers to the first two levels on Wirth's scale and the adopted value in this case was ' 1.5 '. Lichen species not mentioned in these two publications were assessed indirectly based on the indicator values for co-occurring species. The overall value for a given site was the mean value of indicators for all species found on a study site.

\subsubsection{Total Index of Pollution}

The concentrations of heavy metals in $H$. physodes thalli collected from the study sites were presented in a standardised format as a Total Index of Pollution (Grodzińska 1978) using the formula: $S j=\sum_{i=1}^{S} y_{i j}$, for: $y_{i j}=\left(x_{i j}-\bar{x}_{i}\right) / \bar{x}_{i}$, where: $x_{i j}-$ observed concentration of $i$-th element in $j$-th sample; $\bar{x}_{i}-$ mean concentration of $i$-th element for all samples.

\subsubsection{Graphical interpolation and statistical analyses}

Spatial distributions of IAP values, mean Wirth's ecological indicator values and accumulation of examined elements in the $H$. physodes thalli were presented on the map of Gorce National Park using the Inverse Distance Weighted (IDW) interpolation method in Quantum GIS v. 2.18.20 software. As sulfur concentration had been measured by using different methodologies throughout years of study, the sulfur pollution comparison was neglected and the spatial distributions of this element were only compared.

Data were processed using Statistica v. 13.1 and Canoco v. 5. software. Generalised linear model with Poisson distribution and log link function has been adjusted to predict: the impact on IAP indices, mean values of $\mathrm{L}, \mathrm{R}$ and $\mathrm{N}$ coefficients of Wirth's ecological scale determined for the three years, i.e. 1993, 2013 and 2018, seven trace metals and sulphur measured in 1993 and 2018, and nitrogen measured in 2018. This model is appropriate for abnormally distributed response data based on Braun-Blanquet scale and effective under the assumption that the lichen's response increases approximately exponentially as the concentration of toxic substances grows. The maximum-likelihood approach in the model for the 1993 data was used (when the over dispersion phenomenon did not occur) and the quasilikelihood approach in two latter study years (when dispersion was >1.5). Selection of best predictors in the models for individual years was done by backward elimination based on Wald test. The nonparametric Mann-Whitney U test was applied to compare the ranked ecological indicator values for different forest communities.

The effect of environmental variables on the epiphytic lichen biota associated with spruce (estimated on the Wirth's ecological indicator values as well as the concentrations of $\mathrm{S}, \mathrm{N}$ and heavy metals in $H$. physodes thalli) was also checked based on species abundances for each of the three research periods. Redundancy Analysis (RDA) was performed to assess the influence of that data in explaining the variance of the coefficient $f$ (from the IAP equation) calculated for each lichen species from a study plot according to the criteria shown in Table 1. Analyses were performed on the basis of 999 unrestricted, random permutations and the significance of the model, and the ordination axis were tested using pseudo-F statistics based on the sum of all canonical eigenvalues (Miller 1975). The response data were previously centred by columns and square transformed in order to normalize their distribution and limit the effect of most dominant species. Most influencing environmental variables were sequentially added to the model using forward selection method. Only those species, for which the frequency on a site in a given period was higher than 5\%, were analysed (Table 2). Species, for which the variances had not been sufficiently explained by the fitted model on the basis of their response curves, were removed in the last step. 
Table 2 Lichen species used in a multivariate analysis which exceeded the frequency of $5 \%$ per plot at least in one research term and abbreviations of their names.

\begin{tabular}{|c|c|}
\hline Species name & Abbreviation \\
\hline Biatora veteranorum & B.vet. \\
\hline Calicium abietinum & C.abi. \\
\hline Chaenotheca chrysocephala & C.chr. \\
\hline Chaenotheca ferruginea & C.fer. \\
\hline Chaenotheca furfuracea & C.fur. \\
\hline Chaenotheca stemonea & C.ste. \\
\hline Chaenotheca trichialis & C.tri. \\
\hline Cladonia coniocraea & C.con. \\
\hline Cladonia digitata & C.dig. \\
\hline Cladonia polydactyla & C.pol. \\
\hline Cladonia pyxidata s.l. & C.pyx. \\
\hline Cladonia squamosa & C.squ. \\
\hline Coenogonium pineti & C.pin. \\
\hline Hypocenomyce scalaris & H.sca. \\
\hline Hypogymnia farinacea & H.far. \\
\hline Hypogymnia physodes & H.phy. \\
\hline Imshaugia aleurites & I.ale. \\
\hline Japewia subaurifea & J.sub. \\
\hline Lecanora conizaeoides & L.con. \\
\hline Lecanora pulicaris & L.pul. \\
\hline Lecidea leprarioides & L.lep. \\
\hline Lecidea nylanderi & L.nyl. \\
\hline Lepraria ssp. & L.spp. \\
\hline Micarea botryoides & M.bot. \\
\hline Micarea micrococca s.l. & M.mic. \\
\hline Micarea prasina s.l. & M.pra. \\
\hline Nephromopsis chlorophylla & N.chl. \\
\hline Palicella filamentosa & P.fil. \\
\hline Parmeliopsis ambigua & P.amb. \\
\hline Parmeliopsis hyperopta & P.hyp. \\
\hline Placynthiella dasaea & P.das. \\
\hline Placyntiella icmalea & P.icm. \\
\hline Platismatia glauca & P.gla. \\
\hline Pseudevernia furfuracea & P.fur. \\
\hline Psilolechia clavulifera & P.cla. \\
\hline Scoliciosporum chlorococcum & S.chl. \\
\hline Trapelia corticola & T.cor. \\
\hline Trapeliopsis flexuosa & T.fle. \\
\hline Trapeliopsis pseudogranulosa & T.pse. \\
\hline Violella fucata & V.fuc. \\
\hline Xylopsora caradocensis & X.car. \\
\hline
\end{tabular}

Variation partitioning procedure (Borcard et al. 1992) was performed between two distinct groups of tested predictors, i.e. ecological indices and chromium, to identify the importance of its simple and conditional effects on the response variables.

\section{Results}

\subsection{Accumulation of elements in Hypogymmia physodes thalli (Appendix 2)}

The mean concentration of $\mathrm{S}$ in 1993 was $0.23 \%$ d.w. (0.105\%-0.315\% d.w.) and in 2018 it was $0.094 \%$ d.w. (0.03\%-0.15\% d.w.), whereas the mean content of $\mathrm{N}$ measured in 2018 was $1.585 \%$ d.w. (0.993\%-2.383\% d.w.).

Regarding heavy metals, a trend towards their increased deposition in $H$. physodes thalli has been observed. A standardised total index for heavy metals $(\mathrm{Sj})$ was in the range of 2.777-5.536 in 1993 and 3.602-8.712 in 2018. Significant changes in the concentrations of 4 analysed elements were found between the examined years. The mean concentration of $\mathrm{Cr}$ reduced from $5.48 \mathrm{ppm}$ to 0.88 ppm. On the other hand, there was an effective increase in the concentration of other elements: $\mathrm{Mn}$ (from 42.67 to $235.59 \mathrm{ppm}$ ), Ni (from 2.18 to $5.83 \mathrm{ppm}$ ) and Cd (from 1.07 to $1.59 \mathrm{ppm}$ ).

\subsection{IAP}

The values of IAP on study plots in 1993 were in the range of $14.5-56.2(\bar{x}=32.4)$. After two decades, in 2013, IAP was in the range of 6.6-50.7 $(\bar{x}=27.5)$. The fall in IAP during that period was caused by a decreasing rate of trunk coverage with epiphytic lichens from $46.0 \%$ to $28.3 \%$. A significant $(\alpha=0.05)$ decrease in share of dominant species was observed for: Lecanora conizaeoides, Hypogymnia physodes, Xylopsora caradocensis and sensitive foliose species from the genera Usnea and Parmeliopsis as well as Platismatia glauca, Pseudevernia furfuracea and Nephromopsis chlorophylla. In 2018 the mean IAP index increased again reaching values between 9.2-62.2 $(\bar{x}=36.9)$. The trend observed in 2013-2018 was associated both with an increase in the number (from 11 to 13 per plot on average) and the appearance frequency of crustose and shadetolerant species from the genera Chaenotheca and Micarea. The mean trunk coverage (30.4\%) was comparable to the one in 2013. The list of IAP indicator values in the three research years is given in Appendix 3.

\subsection{Relationships between IAP, accumulation of elements and ecological indicator values}

The research showed no significant correlation ( $\alpha=0.05$; Table 3) between the IAP values and 
Table 3 Spearman's ranked correlation coefficient $\left(r_{s}\right)$ values between the IAP value and the mean of ecological scale indicator ( $L$ - insolation index, $R$ - substrate reaction index, N - nutrition index; according to Wirth (2010) and Fabiszewski and Szczepańska (2010)), and the content of accumulated elements in Hypogymnia physodes thalli on study plots in Gorce NP in the three research years: 1993, 2013 and 2018. Statistically significant $(p<0.05) r_{s}$ values are in bold. Only interrelated indicators were compared.

\begin{tabular}{|c|c|c|c|c|c|c|c|c|}
\hline \multirow{3}{*}{\multicolumn{3}{|c|}{ Environmental variables }} & \multicolumn{3}{|c|}{ IAP } & \multicolumn{3}{|c|}{ Ecological indices } \\
\hline & & & \multirow{2}{*}{1993} & \multirow{2}{*}{2013} & \multirow{2}{*}{2018} & \multirow{2}{*}{$\begin{array}{l}1993 \\
R\end{array}$} & \multicolumn{2}{|c|}{2018} \\
\hline & & & & & & & $R$ & $N$ \\
\hline \multirow{9}{*}{$\begin{array}{l}\text { Ecological } \\
\text { indices }\end{array}$} & \multirow{3}{*}{$\begin{array}{l}1993 \\
(n=33)\end{array}$} & $L$ & 0.34 & & & & & \\
\hline & & $R$ & 0.06 & & & & & \\
\hline & & $N$ & -0.68 & & & & & \\
\hline & \multirow{3}{*}{$\begin{array}{l}2013 \\
(n=33)\end{array}$} & $L$ & & 0.38 & & & & \\
\hline & & $R$ & & -0.54 & & & & \\
\hline & & $N$ & & -0.62 & & & & \\
\hline & \multirow{3}{*}{$\begin{array}{l}2018 \\
(n=33)\end{array}$} & $L$ & & & 0.34 & & & \\
\hline & & $R$ & & & -0.30 & & & \\
\hline & & $N$ & & & -0.65 & & & \\
\hline \multirow{19}{*}{ Elements } & \multirow{9}{*}{$\begin{array}{l}1993 \\
(n=30)\end{array}$} & $\mathrm{S}$ & -0.03 & & & -0.08 & & \\
\hline & & $\mathrm{Mn}$ & 0.27 & & & -0.08 & & \\
\hline & & $\mathrm{Zn}$ & -0.1 & & & -0.09 & & \\
\hline & & $\mathrm{Cu}$ & 0.06 & & & -0.04 & & \\
\hline & & $\mathrm{Pb}$ & -0.05 & & & -0.21 & & \\
\hline & & $\mathrm{Cd}$ & 0.02 & & & 0.12 & & \\
\hline & & $\mathrm{Ni}$ & -0.27 & & & 0.07 & & \\
\hline & & $\mathrm{Cr}$ & 0.01 & & & -0.05 & & \\
\hline & & $\mathrm{Sj}$ & -0.10 & & & -0.01 & & \\
\hline & \multirow{10}{*}{$\begin{array}{l}2018 \\
(n=30)\end{array}$} & $\mathrm{S}$ & & & -0.24 & & 0.02 & 0.09 \\
\hline & & $\mathrm{N}$ & & & 0.02 & & -0.12 & -0.02 \\
\hline & & $\mathrm{Mn}$ & & & -0.28 & & 0.17 & 0.16 \\
\hline & & $\mathrm{Zn}$ & & & 0.13 & & 0.1 & -0.21 \\
\hline & & $\mathrm{Cu}$ & & & 0.00 & & -0.13 & -0.22 \\
\hline & & $\mathrm{Pb}$ & & & 0.09 & & 0.00 & -0.11 \\
\hline & & $\mathrm{Cd}$ & & & 0.33 & & -0.02 & -0.38 \\
\hline & & $\mathrm{Ni}$ & & & -0.04 & & 0.03 & -0.11 \\
\hline & & $\mathrm{Cr}$ & & & 0.09 & & -0.08 & -0.14 \\
\hline & & $\mathrm{Sj}$ & & & 0.19 & & -0.12 & $-\mathbf{0 . 3 7}$ \\
\hline
\end{tabular}

concentrations of both sulfur and heavy metals in the same plots in 1993, although manganese $\left(r_{s}=\right.$ o.27) and nickel $\left(r_{s}=-0.27\right)$ had a moderate impact. The cumulative impact of examined metals $(\mathrm{Sj}$ index) on IAP values in the first term was weakly negative $\left(r_{s}=-0.10\right)$. In 2018 a stronger but still insignificant negative correlation between IAP and concentration of $\mathrm{S}\left(r_{s}=-0.24\right)$ was observed, whereas no correlation of IAP with the content of $\mathrm{N}$ occured. In contrast to 1993, the correlation of IAP with $\mathrm{Mn}$ in 2018 reversed completely, although it was still not significant $\left(r_{s}=-0.28\right)$. In the same time period, a positive correlation of IAP with $\mathrm{Cd}$ increased considerably (to $\mathrm{r}_{\mathrm{s}}=0.33$ ) and $\mathrm{Sj}$ index changed to weakly positive $\left(r_{s}=0.19\right)$.

In 2013 and 2018 IAP values was influenced with the type of forest community, being higher in subalpine spruce forests than in mixed forests at lower altitudes (Figures 1 \& 2). The spatial distribution of deposited heavy metals ( $\mathrm{Sj}$ index) for both years indicate the multidirectional transport of these pollutants, mainly determined by the course of river valleys, where metals are deposited usually on mountain slopes at lower altitudes. The air contaminated with $\mathrm{S}$ and $\mathrm{N}$ mainly flows from the north and north-east, i.e. from industrialized regions of Upper Silesia and Kraków, as indicated by the increased concentrations of these elements on the windward slopes of the highest hills (Figure 1).

Knowing the environmental requirements of lichens, Wirth (2010) developed an ecological scale in which individual species are assigned optimal values of physical parameters of the environment, just like in the Ellenberg scale created for vascular plants (Ellenberg 1974; Ellenberg et al. 1992). The light indicator (L) for lichens surveyed in Gorce NP was in the range of 3-8. Most species were assigned value 5 (46\% observations) corresponding with semi-shaded habitats $(>10 \%$ of relative 


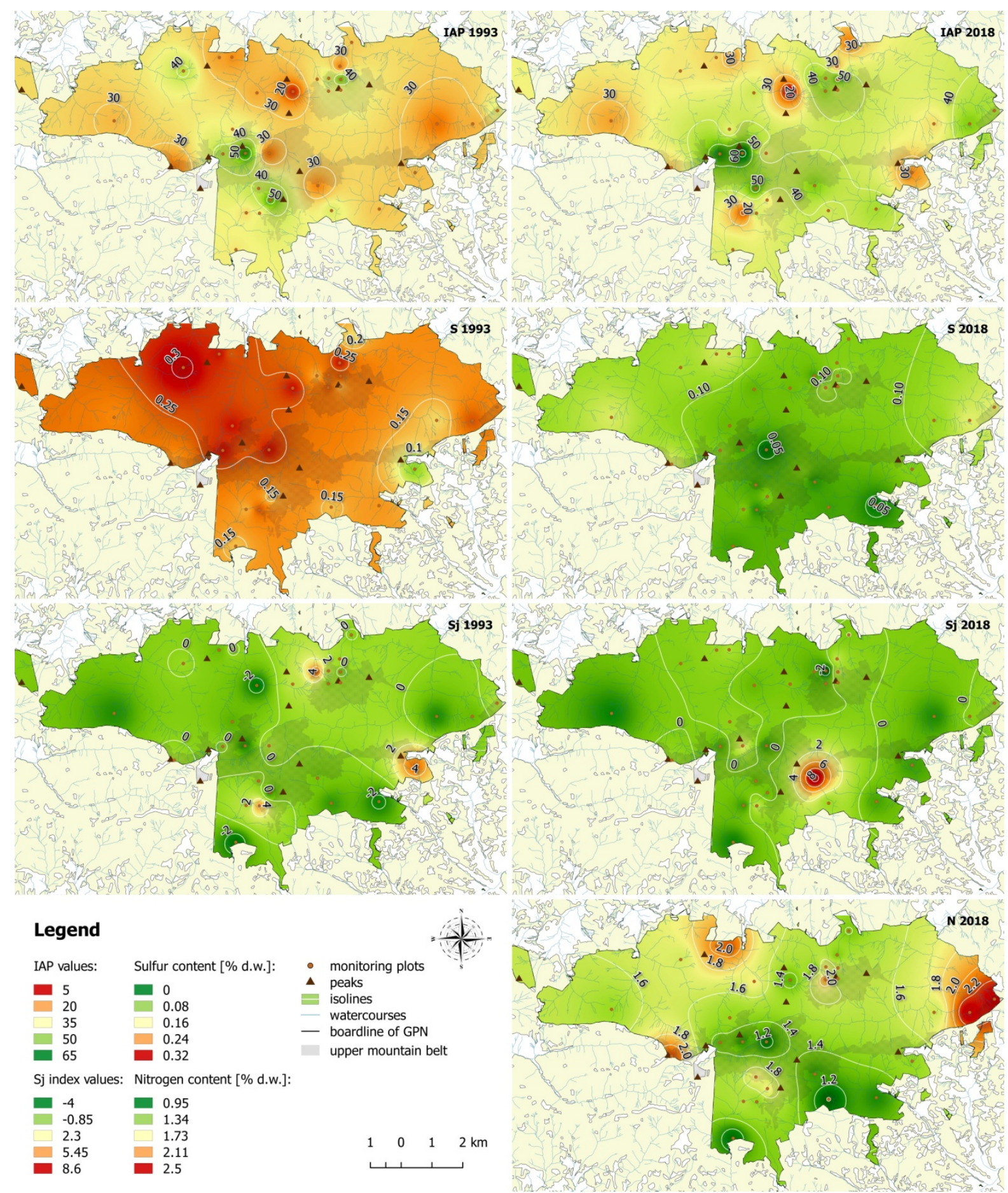

Figure 1 Spatial interpolation of IAP index values and the content of elements: $\mathrm{S}, \mathrm{N}$ and heavy metals $(\mathrm{Cr}, \mathrm{Mn}, \mathrm{Cu}$, $\mathrm{Zn}, \mathrm{Ni}, \mathrm{Cd}, \mathrm{Pb}$ ), assigned as the total pollution index $(\mathrm{Sj})$ in $H$. physodes thalli on 30 examined sites in Gorce NP in 1993 and 2018, against the background of the upper mountain belt; IDW interpolation method in Quantum GIS v. 2.18.20 software have been used.

intensity of natural light). It was found, that $\mathrm{L}$ values differ between sites depending on the type of forest community. The optimum values of light assigned to species found in subalpine spruce forests $(P-P)$ were higher than that in the
Carpathian beech forest of lower belt $(D g-F)$ and had significantly different distributions (Table 4). The L indicator in each study year correlated with IAP at the level of $r_{s}>0.3$ (Table 3), but the correlation was statistically significant only in 2013 . 
The comparison of spatial distributions of IAP values and $\mathrm{L}$ indicator values for 2013 revealed that higher availability of light on the plots corresponded with IAP values mainly in subalpine spruce forests, although this trend is not persistent, as is indicated by the drop in the correlation magnitude in 2018.

The $\mathrm{R}$ indicator value (range of 1.5-5.5) was found to be 2 in most cases (44\%) and pointed to

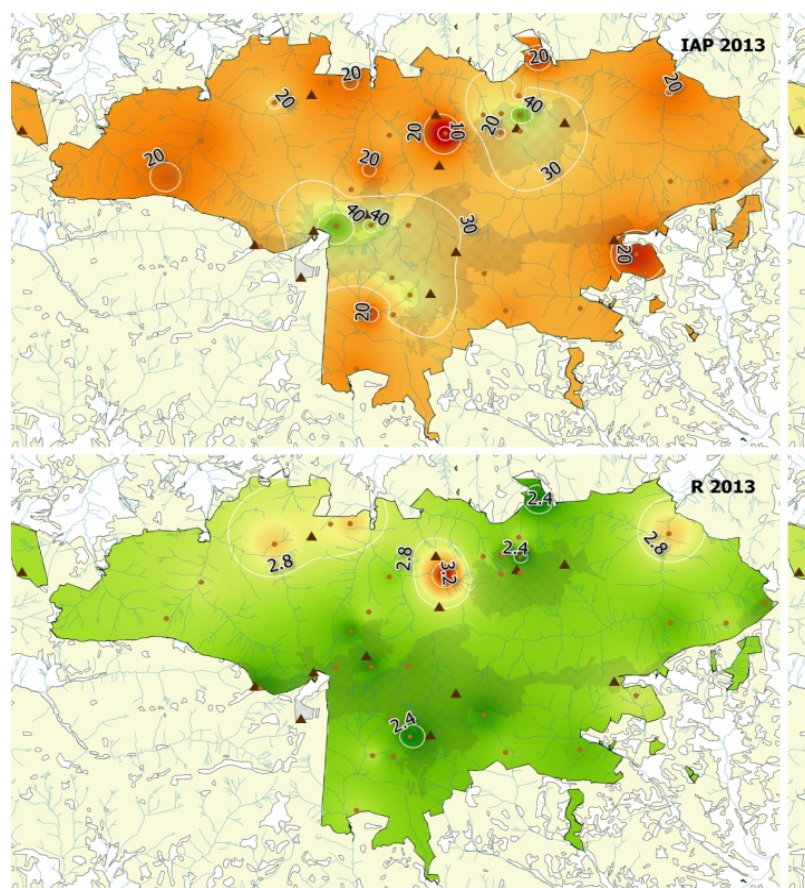

\section{Legend}

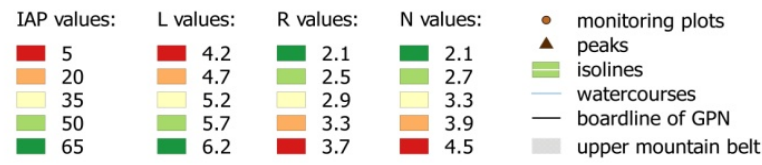

the dominance of very acidic habitats with $\mathrm{pH}$ of 3.4-4.0 (Wirth 2010). In 1993 the R median was higher in the subalpine spruce forest $(P-P)$, whereas the relation reversed in 2013 and 2018 (Table 4). The correlation between IAP and mean R distributions in 1993 was not significant (Table 3), but in two latter study years the correlation values between these indicators ranks expanded, i.e. $r_{s 2013}=-0.54$ and $r_{s 2018}=-0.30$ (Table 3), becoming

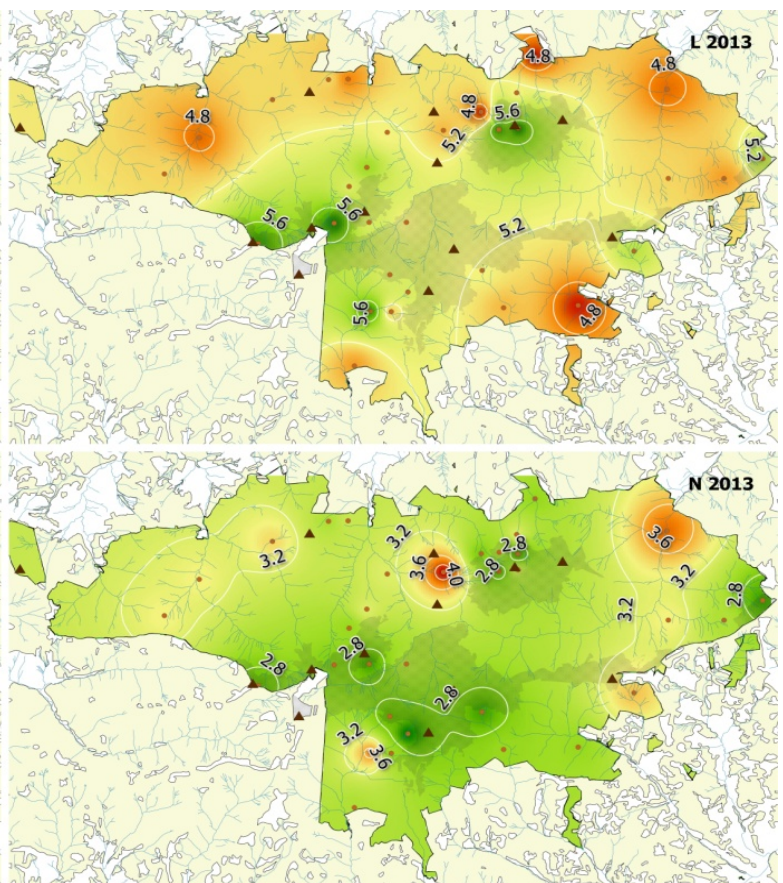

Figure 2 Spatial interpolation of the IAP values and the mean values of ecological indicators for insolation (L), reaction (R) and nutrition $(\mathrm{N})$ in 2013 on 33 examined sites in Gorce NP, against the background of the upper mountain belt; IDW interpolation method in Quantum GIS v. 2.18.20 software have been used.

Table 4 Results of Mann-Whitney $U$ with continuity correction statistic for independent samples between the means of L, R and N coefficients of the ecological scale by Wirth (2010) and Fabiszewski and Szczepańska (2010) in two forest communities: Dentario glandulosae-Fagetum $(D g-F ; n=22)$ and Plagiothecio-Piceetum $(P-P ; n=11)$ in 1993 , 2013 and 2018. Statistically significant $p$ values $(\alpha<0.05)$ are in bold.

\begin{tabular}{|c|c|c|c|c|c|c|c|c|}
\hline $\begin{array}{l}\text { Ecological } \\
\text { indices }\end{array}$ & $\begin{array}{l}\text { Median } \\
D g-F\end{array}$ & $\begin{array}{l}\text { Median } \\
P-P\end{array}$ & $\begin{array}{l}\text { Rank sum } \\
D g-F\end{array}$ & $\begin{array}{l}\text { Rank sum } \\
P-P\end{array}$ & $U$ & $\begin{array}{l}Z \\
\text { (adjusted) }\end{array}$ & $p$ & $\begin{array}{l}2 \times 1 \text { sided } \\
\text { exact } p\end{array}$ \\
\hline L 1993 & 5.6 & 5.9 & 282.5 & 278.5 & 29.5 & -3.47786 & 0.001 & 0.000 \\
\hline R 1993 & 2.6 & 2.7 & 323 & 238 & 70 & -1.93067 & 0.054 & 0.053 \\
\hline N 1993 & 3.0 & 2.9 & 399.5 & 161.5 & 95.5 & 0.9569 & 0.339 & 0.336 \\
\hline L 2013 & 5.1 & $5 \cdot 5$ & 276.5 & 284.5 & 23.5 & -3.70655 & O & 0.000 \\
\hline R 2013 & 2.7 & 2.5 & 461 & 100 & 34 & $3 \cdot 30615$ & 0.001 & 0.000 \\
\hline $\mathrm{N} 2013$ & 3.1 & 2.7 & $455 \cdot 5$ & 105.5 & 39.5 & 3.09412 & 0.002 & 0.001 \\
\hline L 2018 & 4.9 & $5 \cdot 5$ & 273.5 & 287.5 & 20.5 & -3.82118 & $\mathrm{O}$ & 0.000 \\
\hline R 2018 & 2.6 & 2.4 & 436 & 125 & 59 & 2.34944 & 0.019 & $\mathbf{0 . 0 1 7}$ \\
\hline N 2018 & 3 & 2.7 & 441.5 & 119.5 & 53.5 & 2.56062 & 0.01 & 0.008 \\
\hline
\end{tabular}


a relevant trend in the second term.

The indicator value for nutrients $(\mathrm{N})$ ranged from 1 (habitats poor in nutrients) to 5 (mesotrophic habitats), where the most frequent values were 2 and 3 corresponding with loweutrophicated or non-eutrophicated habitats (47\% observations in total), respectively. Higher $\mathrm{N}$ values characterised Carpathian beech forest $(D g-F)$ in each study year (Table 4), but significant differences were found in 2013 and 2018. In subsequent years the $\mathrm{N}$ indicator ranks significantly correlated with IAP (Table 3), and considering all analysed factors, the eutrophication had the strongest negative effect on the lichen biota associated with spruce. Increased IAP values corresponded to decreased mean values of $\mathrm{N}$ indices on a study plot and simultaneously the occurrence of more nitrophilous species correlated significantly negatively with cadmium contamination $\left(r_{s}=-0.38\right)$.

\subsection{Generalized linear model for assessing accumulation of elements and ecological indicator values as predictors of IAP}

For the further consideration of the effects of the individual predictors tested on the IAP values in each study year, generalized linear models were built based on the Poisson distribution (Table 5). Models fit were tested by using Pearson $\chi^{2}$ test and analyses of residuals. The model for 1993 was the best fitted one $\left(\chi^{2} / \mathrm{df}=1.07\right)$, where both $\mathrm{L}$ and $\mathrm{N}$ indices as well as cumulated nickel content were significant predictors of IAP $(\alpha=0.05)$. In the model for $2013 \mathrm{~N}$ index was significant wherein $\chi^{2} / \mathrm{df}=1.82$. Finally, in $2018 \mathrm{~N}$ index, $\mathrm{Cd}$ and $\mathrm{Mn}$ contents were relevant factors, whereas $\chi^{2} / \mathrm{df}=$ 1.64. Each time the $\mathrm{N}$ index was the most negatively related among other factors, indicating that nitrophilous species decreased their share in lichen communities during the last 25 years. At the same time, the reaction coefficient $\mathrm{R}$ was not influential in any of the models, and the light index L was significant only in the first research term. That is incompatible with Spearman's correlation of these variables, shown in Table 3, where IAP correlated positively and significantly with an increase of both photophilous (2013) and acidophilous $(2013,2018)$ species. Accumulated nitrogen in 1993 turned out to be a better predictor for IAP values than photophilous species, despite being less correlated to it (see Table 3). The same was true for $\mathrm{Mn}$ and $\mathrm{Cd}$, which abundances were more powerful in the model than slightly better correlated $\mathrm{L}$ and $\mathrm{R}$ indicators. The differences are resulting from an interaction effect occurring between predictors included in the model.

Table 5 Statistically significant $(\alpha=0.05)$ parameters in the fitted regression models on the basis of Wald's statistics together with their regression coefficients (b) and standard errors (SE).

\begin{tabular}{|c|c|c|c|c|c|}
\hline \multicolumn{2}{|c|}{ Factors } & $b$ & $S E$ & $W$ & $p(W)$ \\
\hline \multirow{4}{*}{1993} & (Intercept) & 4.8581 & 0.84913 & 35.06 & 0.00000 \\
\hline & $\mathrm{N}$ & -0.93276 & 0.17253 & 31.3 & 0.00000 \\
\hline & $\mathrm{Ni}$ & -0.05784 & 0.02139 & 7.83 & 0.00515 \\
\hline & $\mathrm{L}$ & 0.26694 & 0.10860 & 6.47 & 0.01097 \\
\hline \multirow{2}{*}{2013} & (Intercept) & 5.37628 & 0.40932 & 172.52 & 0.00000 \\
\hline & $\mathrm{N}$ & -0.68890 & 0.13767 & 25.04 & 0.00000 \\
\hline \multirow{4}{*}{2018} & (Intercept) & 5.25654 & 0.36766 & 204.41 & 0.00000 \\
\hline & $\mathrm{N}$ & -0.56709 & 0.12052 & 22.14 & 0.00000 \\
\hline & $\mathrm{Cd}$ & 0.11763 & 0.05455 & 4.65 & 0.03105 \\
\hline & Mn & -0.00071 & 0.00035 & 4.12 & 0.04238 \\
\hline
\end{tabular}

\subsection{Multivariate analysis}

RDA for individual study years identified significant environmental factors $(\alpha=0.05)$, their directions and magnitude of effect on the presence of epiphytic lichens on spruce trees (Figure 3A-C). The analysis of data for 1993 (L, R, N, sulfur, 7 metals, $\mathrm{Sj}$ ) explained $43.0 \%$ of the total variance for species composition $(34.8 \%$ of adjusted variance, $p=0.001$; Tables 6 and 7). Factors with a significant influence included the three indicator values and chromium (Table 7). $\mathrm{L}$ and $\mathrm{N}$ indices

Table 6 Explained variation (EV) and adjusted explained variation (Adj. EV) in models for 1993, 2013 and 2018 and per axis statistics for significant Redundancy Analysis (RDA) axis; CEV - cumulative explained variation.

\begin{tabular}{|c|c|c|c|c|c|c|c|}
\hline Model statistics & \multicolumn{2}{|c|}{ RDA 1993} & \multicolumn{3}{|c|}{ RDA 2013} & \multicolumn{2}{|c|}{ RDA 2018} \\
\hline $\mathrm{EV}$ & \multicolumn{2}{|l|}{$43.0 \%$} & \multicolumn{3}{|l|}{$34.1 \%$} & \multicolumn{2}{|l|}{$37.8 \%$} \\
\hline Adj. EV & \multicolumn{2}{|l|}{$34.8 \%$} & \multicolumn{3}{|l|}{$27.3 \%$} & \multicolumn{2}{|l|}{$33.2 \%$} \\
\hline Axes statistics & RDA 1 & RDA 2 & RDA 1 & RDA 2 & $\mathrm{RDA}_{3}$ & RDA 1 & RDA 2 \\
\hline Eigenvalues & 0.2868 & 0.0856 & 0.2215 & 0.0709 & 0.0489 & 0.2886 & 0.0893 \\
\hline $\mathrm{CEV}$ & $28.7 \%$ & $37.3 \%$ & $22.2 \%$ & $29.2 \%$ & $34.1 \%$ & $28.9 \%$ & $37.8 \%$ \\
\hline Pseudo-F & 8.3 & 3.8 & 8.3 & 2.9 & 2.2 & 12.9 & 3.5 \\
\hline$p$ & 0.001 & 0.001 & 0.001 & 0.001 & 0.015 & 0.001 & 0.001 \\
\hline
\end{tabular}


Table 7 Linear correlation coefficients between notable environmental variables and the first tree significant canonical axes $(p=0.001)$ in Redundancy Analysis (RDA) in the models for 1993, 2013 and 2018.

\begin{tabular}{ll|l|l|l} 
Model test & Factors & RDA 1 & RDA 2 & RDA 3 \\
RDA 1993 & Light $(L)$ & -0.79 & 0.41 & \\
pseudo- & Reaction $(R)$ & -0.31 & 0.65 & \\
$F=5.3$ & Eutrophication $(N)$ & 0.63 & 0.51 & \\
RDA 2013 & Cromium $(C r)$ & -0.22 & -0.19 & \\
Lseudo- & Reaction $(R)$ & -0.71 & -0.34 & 0.61 \\
$F=12.8$ & Eutrophication $(N)$ & 0.79 & -0.61 & 0.07 \\
RDA 2018 & Light $(L)$ & -0.19 & 0.57 \\
$\begin{array}{l}\text { pseudo- } \\
F=12.5\end{array}$ & Eutrophication $(N)$ & -0.74 & 0.54 & \\
& & & &
\end{tabular}

were the most important factors, the first of which was negatively and the second positively correlated with the first ordination axis. $\mathrm{R}$ index was better positively related to second axis, and $\mathrm{Cr}$ accumulation was about equally related to both of them. Based on variation partitioning procedure, only the conditional effects of $\mathrm{Cr}$ were significant, but not their simple effects, meaning that they were not significant as an independent variable. The weak influence of chromium is also shown on the species-environmental variables biplot on the Figure 3A. The 2013 analysis tested ecological indicator values only (the concentrations of elements were not measured that year). The model was significant at the level of $p=0.001$. All three indicator values had a significant effect on the species composition at that time, explaining in total $34.1 \%$ of data variance (Table 6). The best correlation with the first two axis (Table 7) was found for reaction index (R), which is thus constituted the best predictor. L was highly correlated with all three significant axis whereas $\mathrm{N}$ with the first and the third of them. Among thirteen analysed variables in 2018 (L, N, R, sulfur, nitrogen, 7 metals, $\mathrm{Sj}$ ), two were significant and explained together $37.8 \%$ of the total $(33.2 \%$ adjusted) variance of the community structure $(p=$ o.001; Tables 6 \& 7). These were $\mathrm{L}$ and $\mathrm{N}$ values, well correlated with two first RDA axis (Table 7). The concentrations of heavy metals measured either separately or jointly in lichen thalli in two study years, with the exception of $\mathrm{Cr}$ in 1993, had no significant effect on the frequency and constancy of lichen species.

\section{Discussion}
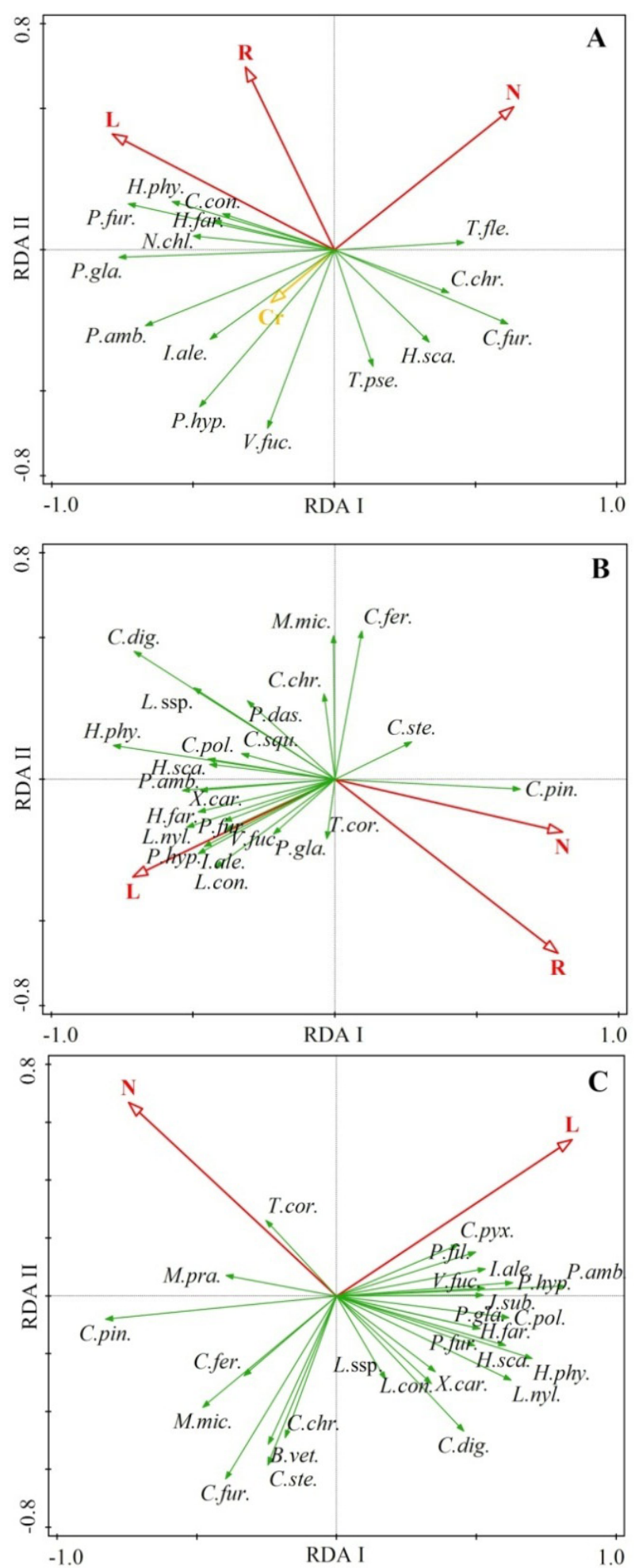

Figure 3 Redundancy Analysis (RDA) ordination charts between the $f$ coefficient and significant $(\alpha<0.05)$ environmental variables determined on the basis of ecological scale indicators (Wirth 2010) for insolation $(\mathrm{L})$, reaction $(\mathrm{R})$ and nutrition $(\mathrm{N})$ (red vectors) and the chromium content $(\mathrm{Cr})$ in $H$. physodes thalli (yellow vector) in three years: 1993 (A), 2013 (B) and 2018 (C). 
For the purpose of air quality assessment in the studied sites, the IAP index was determined, based on the phytosociological parameters of epiphyte communities, such as: species composition, coverage of the examined bark patch by each species and the constancy of their occurrence. Despite the obvious weakness of treating all species equally, it is widely recognized as being effective in its role when it is known that they differ in tolerance to pollution and microclimatic conditions. The assumptions for its use are met, as long as pollution is a limiting factor for the occurrence of lichens. Otherwise, as in many ecosystems of natural forests away from emission sources, the determinant are microclimatic factors, modified by the continuity and diversity of the ecosystem and the dynamics of forest communities, as well as the substrate properties.

The mean concentrations of $\mathrm{S}$ and $\mathrm{N}$ in Gorce range measured in lichen thalli in 2018 were comparable to those measured with the same methods in 2015 in samples of the same lichen species transplanted to the area of Rzeszów (a city of a population of 200.000), located ca. $200 \mathrm{~km}$ east of Gorce range, reaching $0.133 \%$ d.w. and $1.248 \%$ d.w. of sulfur and nitrogen, respectively (Tanona et al. 2017). Similar results were reported that time in a control sample collected from large Solska Forest, i.e. $0.144 \%$ d.w. and $1.22 \%$ d.w. of S and $\mathrm{N}$ in thalli, respectively.

In 2018 the concentrations of trace metals (except $\mathrm{Ni}$ ) in lichen thalli from the GNP were slightly lower than the levels measured by Klimek et al. (2015) in thalli of $H$. physodes collected in five towns located in the Western Beskidy Mts. The heavy metals pollution level in Gorce National Park in both periods was lower than in nearby Kraków (Białońska and Dayan 2005) and Kielce, located ca. $200 \mathrm{~km} \mathrm{~N}$ of Gorce range (Jóźwiak 2007), but higher than in Rzeszów (Tanona et al. 2017). The above results suggest that the inflow of pollutants from Upper Silesia and Kraków regions might have an important effect on the air quality in this range.

Considering the well examined, clear and adequate biological response of lichens to the presence of toxic elements and compounds $\left(\mathrm{SO}_{2}\right.$, $\mathrm{NO}_{\mathrm{x}}$ and heavy metals) in urban areas (e.g. Ranta 2001; Bačkor et al. 2003), the zones designated by the interpolation of IAP values in the forested area of Gorce National Park could, at least partially, correspond with the accumulation of total sulfur, nitrogen and/or the content of metals in the sampled thalli. In the light of our results, i.e. the lack of clear correlation between IAP and air pollutants accumulated in lichen thalli, the use of this method for the assessment of air pollution in large mountain natural forests seems to be at least controversial. At the same time, the phytosociological IAP index was better correlated to Wirth's ecological scale indicators. This most likely results from the positive response to forest decomposition caused by natural disasters in recent years, such as bark beetle outbreaks and hurricane winds.

The important effect of light on the biodiversity and distribution of lichens in forests, which has been recently emphasized i.a. by Sales et al. (2016), Sevgi et al. (2019) and Vondrák et al. (2019), showed up here in the similarity between spatial distributions of IAP values and L indicator values for 2013.

An increase in correlation between IAP and $\mathrm{R}$ index was observed from the first towards the second and third study year, while the mean concentration of sulfur measured in $H$. physodes thalli was decreasing. In $1993 \mathrm{~S}$ content was almost two-fold higher than the concentration measured in 2018. This shows the simultaneous influence of other factors modifying the response of lichens growing on the sites and explains the lack of correlation between IAP and mean R distributions in 1993 in the first study year.

As it was previously said, the eutrophication ( $\mathrm{N}$ index) had the most harmful effect on the studied lichen biota (Table 3). The negative correlation between both $\mathrm{N}$ and $\mathrm{Sj}$ indices and $\mathrm{Cd}$ concentration, with the simultaneous lack of a relationship between the $\mathrm{N}$ index and nitrogen deposition, indicate that the increase of IAP values was caused by the presence of species tolerating higher concentrations of heavy metals, particularly $\mathrm{Cd}$, and not by the share of nitrophilous species, although this relationship is not statistically significant $\left(r_{s}=0.19\right.$; Table 3$)$. The lack of a significant relationship between the IAP indices and the concentrations of the examined metals in lichen thalli on the same forest plots show that the long-term (25 years) dynamics of the frequency and abundance of lichen species did not 
significantly depend on heavy metal contamination. It means that the level of these elements was and still lies within the tolerance of species inhabiting the monitored forests. Generalized linear model reveals that $\mathrm{N}$ index was the best predictor for IAP in three study years (Table 5). Although it highlighted such metals as $\mathrm{Ni}, \mathrm{Mn}$ and $\mathrm{Cd}$, the impact of accumulated elements on the IAP index is still uncertain and difficult to interpret due to the instability of the direction of interaction (e.g. Mn, see Table 3) as well as surprisingly positive relationships (Cd; see Table 3).

The content of $\mathrm{S}$ and $\mathrm{N}$ in sampled $H$. physodes thalli did not correspond with ecological indicator values describing the share of acidophilous and nitrophilous species (Table 3). The amount of pollutants absorbed and retained by lichens depends on various factors, including: the lichen species, the type of pollutant as well as climate and environmental conditions (Sett and Kundu 2016). Moreover, the deposition of airborne particles on the tree bark surface may depend for example on: microclimatic conditions, topography (altitude, exposure, slope gradient) or tree stand density (Kowalkowski 2003; Xu et al. 2016). The $\mathrm{pH}$ of bark, apart from its natural value, is not determined exclusively by the level of sulfur compounds adsorbed on the bark surface. It can also be reduced by nitrogen compounds, including ammonia and ammonium ions deriving from decomposed organic matter and carbonic acid being the product of the reaction between $\mathrm{H}_{2} \mathrm{O}$ and $\mathrm{CO}_{2}$ (Brimblecombe 1994). Consequently, the spatial distribution of the elements accumulated in lichen thalli may differ from the content of these elements in the air (Liu et al. 2016; Wegrzyn et al. 2016). It shows that the concentrations of toxic elements in sampled lichen thalli could not be used as an ecological indicator in all environmental circumstances, especially in large forests.

Multivariate analyses demonstrated that sulfur and nitrogen deposited in lichen thalli, at levels measured in 1993 and 2018, have no relevant effect on the phytosociological parameters of lichen epiphytes associated with spruce and among heavy metals, only chromium had a certain impact. In each research term the availability of light and nutrients in a given habitat had a substantial effect. Lichen community structure was determined by availability of light in the first and the third study year and by substrate reaction in 2013. Comparison of these results with the generalized regression model related to the IAP indicates that light and reaction are responsible in particular for the species composition of the plot, while nutrients influence rather the diversity and abundance of species.

The IAP value decreased significantly over first 20 years (1993-2013) of observation. During the last period 2013-2018 the IAP value increased again exceeding its initial mean value (see Figures 1 \& 2). A final explanation for the frequency changes and the richness of lichen species associated with Norway spruce should not be sought in the dynamic of air pollution (see Table 3) but in the dynamic of tree stands that took place over the last 25 years in the area of Gorce NP. These changes are mainly driven by bark beetle outbreaks and windstorms. Light availability in the forest may be decisive for the toxic effect of nitrogen at low concentrations (Carter et al. 2017) as well as influence the negative correlation between IAP indices and mean values of $\mathrm{L}$ and $\mathrm{N}$ indicators. Dynamic changes in the lower belt forests of the Gorce range reduce the availability of light on the forest floor because of the vigorous development of undergrowth. It is the main cause for the natural evolution of species composition towards communities tolerant to: shading, higher doses of nutrients and lower acidity of the substrate, which is reflected in higher ecological indicator values $\mathrm{N}$ and $\mathrm{R}$. These conditions are suitable for lichen species, which throughout the study period were characterised by the highest increase of frequency in $D g-F$ forests: Coenogonium pineti $(\mathrm{L}=3, \mathrm{R}=4$, $\mathrm{N}=4)$, Micarea micrococca $(\mathrm{L}=4, \mathrm{R}=1.5, \mathrm{~N}=3.5)$ and Chaenotheca stemonea $(\mathrm{L}=3, \mathrm{R}=3, \mathrm{~N}=2)$. In subalpine spruce forests $P-P$ gaps in post-bark beetle stands persist much longer and pollutants can be leached by rain, which is more frequent in this zone. These conditions promote the expansion of oligotrophic, light-demanding species that prefer acidic phorophyte, for example Hypocenomyce scalaris $(\mathrm{L}=6, \mathrm{R}=2, \mathrm{~N}=2$ ), Lecidea nylanderi ( $\mathrm{L}$ $=5, \mathrm{R}=2, \mathrm{~N}=1)$ and Violella fucata $(\mathrm{L}=5, \mathrm{R}=3$, $\mathrm{N}=3$ ). A significant decrease in the share of foliose and fruticose macrolichens in subsequent study years was observed mainly in the $D g-F$ zone and it can be largely attributed to the gradual shading of study sites. The decrease in the share of these 
species (less significant) in the $P-P$ forest community was most likely caused by sudden changes in microclimate (insolation and humidity) following natural disasters that affected the surviving trees. A more frequent exposure of thalli to direct insolation causes greater evaporation of water from the bark, and thus, as reported by Gauslaa (2014), may consequently limit the growth of species that require higher humidity.

Many researchers have emphasized that the dynamics of lichen biota are driven by many environmental factors (including the most important ones, such as climate, microclimate and substrate properties (e.g. Asta et al. 2002; Giordani 2007; Agnan et al. 2017) as well as human pressure (including transformation of habitats; Chuquimarca et al. 2019), which should not be ignored while interpreting data on the diversity of lichens. At the same time, it should not be forgotten that factors of different origin interact in the environment, so the influence of "natural" factors may also be modified by the anthropogenic factors, even of far-reaching ones.

Asta et al. (2002) reviewed methods for calculating phytosociological lichen indicators and proposed a modified methodology for the assessment of the lichen diversity value, namely LDV. According to the authors, this methodology has a wide range of applications, including nonurban areas, and allows for the long-term impact assessment of environmental stressors, including air pollution, eutrophication, anthropogenic environmental changes and climate change. Agnan et al. (2017) researched natural forests in France and Switzerland and reported only a weak negative correlation between the level of accumulated metallic elements and the LDV index, but no such relationship referred to IAP values, although IAP, LDV and abundance of lichens correlated better with the ecological indicator values for reaction, eutrophication, continentalism and light.

Käffer and de Azevedo Martins (2014) used the original methodology of IAP while investigating virgin-type forests of Brazil and concluded that it was an adequate tool for the identification of areas valuable in terms of lichen biota.

The hereby results correspond well to the above studies, confirming that the original version of the IAP bioindication method can be applied to assess ecological conditions in large Carpathian forests, however not in their validation focused on environmental pollution. A detailed analysis of a range of environmental variables, that could potentially influence the examined epiphytic lichen biota, was not the aim of the present study, but will be the subject of another research paper by authors.

The strengths of using the IAP index in assessing the quality of ecological conditions in forests with a low level of air pollution are: i) the possibility of designating zones of high ecological value in forests, i.e. species rich, weakly affected by human, with preserved continuity of ecological processes; ii) the possibility of assessing the impact of stand dynamic, including various types of disturbances - natural and anthropogenic, on a group of lichens known to be sensitive to changes in their habitats; At the same time, there is a weakness of the method, namely the fact, that the value of the indicator may be determined by tolerant species, occurring in high abundance and with a high constancy. Nevertheless, its equation was constructed in such a way that it was more sensitive to the species diversity of the site than to changes in the surface coverage.

\section{Conclusions}

IAP method is recommended to use for the assessment of ecological conditions in forests. This particularly refers to large natural Carpathian forest, where the concentrations of toxic compounds and elements (to a certain level) are assumed not being the most important criterion determining the growth of lichens. IAP is suitable for the identification of forest patches most valuable in terms of the protection of epiphytes but also for the long-term monitoring of the response of epiphytic lichen biota to local environmental changes induced both by humans and natural causes.

\section{Acknowledgements}

The study was partially financed from a university grant called "Support for young researchers", awarded to MT from the Faculty of Biology and Agriculture, the University of Rzeszów for the academic year 2017/2018 and carried out 
with significant logistical assistance of the Gorce National Park. Open access funding provided by University of Rzeszów, within the CRUI-CARE Agreement. Special thanks go to Mateusz Czarnota for proof reading.

\section{Electronic supplementary material:} Supplementary material (Appendixes 1-3) is available in the online version of this article at https://doi.org/10.1007/s11629-020-6266-1.

\section{References}

Agnan Y, Probst A, Séjalon-Delmas N (2017) Evaluation of lichen species resistance to atmospheric metal pollution by coupling diversity and bioaccumulation approaches: A new bioindication scale for French forested areas. Ecological Indicators 72: 99-110. https://doi.org/10.1016/j.ecolind.2016.08.006

Ammann K, Herzig R, Liebendorfer L, et al. (1987) Multivariate correlation of deposition data of 8 different air pollutants to lichen data in a small town in Switzerland. In: Boehm G, Leuschner RM (eds.), Advances in Aerobiology. Proceedings of the $3^{\text {rd }}$ International Conference on Aerobiology, August 6-9, 1986. EXS, vol. 51. Birkhauser Verlag, Basel. pp 401-406. https://doi.org/10.1007/978-3-0348-7491-5 68

Asta J, Erhardt W, Ferretti M, et al. (2002) Mapping lichen diversity as an indicator of environmental quality. In: Nimis PL, Scheidegger C, Wolseley P (eds.), Monitoring with lichens monitoring lichens. Kluwer Academic, Dordrecht. pp 273-279. https://doi.org/10.1007/978-94-010-0423-7_19

Attanayaka A, Wijeyaratne S (2013) Corticolous lichen diversity, a potential indicator for monitoring air pollution in tropics. Journal of the National Science Foundation of Sri Lanka 41(2): 131-140. https://doi.org/10.4038/jnsfsr.v41i2.5707

Bačkor M, Paulíková K, Geralská A, Davidson R (2003) Monitoring of air pollution in Košice (Eastern Slovakia) using lichens. Polish Journal of Environmental Studies 12(2): 141-150.

Białońska D, Dayan FE (2005) Chemistry of the lichen Hypogymnia physodes transplanted to an industrial region. Journal of Chemical Ecology 31(12): 2975-2991. https://doi.org/10.1007/s10886-005-8408-x

Borcard D, Legendre P, Drapeau P (1992) Partialling out the spatial component of ecological variation. Ecology 73: 1045-1055. https://doi.org/10.2307/1940179

Brimblecombe P (1994) Environmental Acidification. In: Hewitt CN, Sturges WT (eds.), Global Atmospheric Chemical Change. Springer, Dordrecht, pp. 233-270. https://doi.org/10.1007/978-94-015-3714-8 6

Brunialti G, Frati L, Aleffi M, et al. (2010) Lichens and bryophytes as indicators of old-growth features in Mediterranean forests. Plant Biosystems 114: 221-233.

https://doi.org/10.1080/11263500903560959

Bytnerowicz A, Godzik B, Frączek W, et al. (2002) Distribution of ozone and other air pollutants in forests of the Carpathian Mountains in central Europe. Environmental Pollution 116: 3-25. https://doi.org/10.1016/s0269-7491(01)00187-7

Carter TS, Clark CM, Fenn ME, et al. (2017) Mechanisms of nitrogen deposition effects on temperate forest lichens and trees. Ecosphere 8, e01717. https://doi.org/10.1002/ecs2.1717

Chuquimarca L, Gaona F, Iñiguez-Armijos C, Benítez A (2019) Lichen Responses to Disturbance: Clues for Biomonitoring Landuse Effects on Riparian Andean Ecosystems. Diversity 11: 73 https://doi.org/10.3390/d11050073

Cieszkowski M (2006) Scientific geological attractions of Gorce National Park and its surroundings. Ochrona Beskidów Zachodnich 1: 45-57. (In Polish).
Open Access This article is distributed under the terms of the Creative Commons Attribution 4.o International License

(http://creativecommons.org/licenses/by/4.o/), which permits unrestricted use, distribution, and reproduction in any medium, provided you give appropriate credit to the original author(s) and the source, provide a link to the Creative Commons license, and indicate if changes were made.

Czarnota P (1995) Content of micro- and macroelements in Hypogymnia physodes thalli in the Gorce National Park - an attempt to lichen-indication. Parki Narodowe i Rezerwaty Przyrody 14(3): 69-88. (In Polish).

Czarnota P, Kukwa M (2001) Lichens of the genera Lepraria and Leproloma from the Gorce Mts (Western Carpathians, Poland) and note on lichenicolous fungus Paranectria oropensis found on Leproloma membranaceum. Polish Botanical Journal 46(2): 199-206.

Ellenberg H (1974) Zeigerwerte der Gefäßpflanzen Mitteleuropas. Scripta Geobotanica 9: 3-122.

Ellenberg H, Weber HE, Düll R, et al. (1992) Zeigerwerte von Pflanzen in Mitteleuropa. Scripta Geobotanica 18: 3-258.

Fabiszewski J, Szczepańska K (2010) Ecological Indicator values of some lichen species noted in Poland. Acta Societatis Botanicorum Poloniae 79(4): 305-313. https://doi.org/10.5586/asbp.2010.038

Faltynowicz W, Kossowska M (2018) The lichens of Poland. A fourth checklist. Acta Botanica Silesiaca Monographie 8: 3-122.

Gaio-Oliveira G, Dahlman L, Palmqvist K, et al. (2005) Nitrogen uptake in relation to excess supply and its effects on the lichens Evernia prunastri (L.) Ach and Xanthoria parietina (L.) Th. Fr. Planta. 220(5): 794-803.

http://www.jstor.org/stable/23388832

Gauslaa Y (2014) Rain, dew, and humid air as drivers of morphology, function and spatial distribution in epiphytic lichens. The Lichenologist 46: 1-16. https://doi.org/10.1017/Soo24282913000753

Gibson MD, Heal MR, Li Z, et al. (2013) The spatial and seasonal variation of nitrogen dioxide and sulfur dioxide in Cape Breton Highlands National Park, Canada, and the association with lichen abundance. Atmospheric Environment 64: 303-311. https://doi.org/10.1016/j.atmosenv.2012.09.068

Giordani P (2007) Is the diversity of epiphytic lichens a reliable indicator of air pollution? A case study from Italy. Environmental Pollution 146: 317-323. https://doi.org/10.1016/j.envpol.2006.03.030

Gombert S, Asta J, Seaward MRD (2004) Assessment of lichen diversity by index of atmospheric purity (IAP), index of human impact (IHI) and other environmental factors in an urban area (Grenoble, southeast France). Science of the Total Environment 324: 183-199.https://doi.org/10.1016/j.scitotenv.2003.10.036

Gries C (2008) Lichens as indicators of air pollution. In: Nash TH III (ed.), Lichen biology. 2nd edn. Cambridge University Press, London. pp 240-254. https://doi.org/10.1007/978-3-540-47343-5-1

Grodzińska K (1978) Mosses as bioindicators of heavy metal pollution in Polish national parks. Water Air and Soil Pollution 9: 83-97. https://doi.org/10.1007/BFo0185749

Jayalal U, Ileperuma O, Wolseley P, et al. (2017) Correlation of atmospheric purity index to the diversity of lichens in the Horton Plains National Park, Sri Lanka. Ceylon Journal of Sciece 46(2): 13-29. https://doi.org/10.4038/cjs.v46i2.7426

Jeran Z, Jacimovic R, Batic F, et al. (2002) Lichens as integrating 
air pollution monitors. Environmental Pollution 120: 107-113. https://doi.org/10.1016/s0269-7491(02)o0133-1

Jóźwiak M (2007) Accumulation of heavy metals and morphological changes in thalli of Hypogymnia physodes (L.) Nyl. lichen. Monitoring Środowiska Przyrodniczego 8: 51-56. (In Polish).

Käffer MI, de Azevedo Martins SM (2014) Evaluation of the environmental quality of a protected riparian forest in Southern Brazil. Bosque (Valdivia) 35(3): 325-336.

https://doi.org/10.4067/So717-92002014000300007

Klimek B, Tarasek A, Hajduk J (2015) Trace element concentrations in lichens collected in the Beskidy Mountains, the Outer Western Carpathians. Bulletin of Environmental Contamination and Toxicology 94(4): 532-536.

https://doi.org/10.1007/s00128-015-1478-8

Kowalkowski A (2003) Methods of atmospheric air quality and substances deposition states evaluation in the monitoring of forest ecosystems. Regionalny Monitoring Środowiska Przyrodniczego 4:31-55. (In Polish).

Kricke R, Loppi S (2002) Bioindication: The I.A.P. Approach. In: Nimis PL, Scheidegger C, Wolseley PA (eds.), Monitoring with lichens - monitoring lichens. Kluwer Academic, vol 7. Springer, Dordrecht. pp 21-37.

https://doi.org/10.1007/978-94-010-0423-7 4

Kularatne KIA, De Freitas Ch (2013) Epiphytic lichens as biomonitors of airborne heavy metal pollution. Environmental and Experimental Botany 88: 24-32.

https://doi.org/10.1016/j.envexpbot.2012.02.010

LeBlanc F, De Sloover J (1970) Relation between industrialization and the distribution and growth of epiphytic lichens and mosses in Montreal. Canadian Journal of Botany 48: 1485-1496.

Liu HJ, Fang SB, Liu SW, et al. (2016) Lichen elemental composition distinguishes anthropogenic emissions from dust storm inputs and differs among species: Evidence from Xilinhot, Inner Mongolia, China. Scientific Reports 6: 34694. https://www.nature.com/articles/srep34694

Loch J, Armatys P (2008) Primeval Carpathian forest in the Gorce Mts. - history, state of preservation and problems of protection. Roczniki Bieszczadzkie 16: 109-124.

Mateos A, González C (2016) Physiological response and sulfur accumulation in the biomonitor Ramalina celastri in relation to the concentrations of $\mathrm{SO}_{2}$ and $\mathrm{NO}_{2}$ in urban environments. Microchemical Journal 125: 116-123.

https://doi.org/10.1016/j.microc.2015.11.025

Miczyński J (2015) Klimat rządzi przyrodą. In: Czarnota P, Stefanik M (eds.), Gorczański Park Narodowy - przyroda i krajobraz pod ochroną. Gorczański Park Narodowy, Poręba Wielka.

Miller J (1975) The sampling distribution and a test for the significance of the bimultivariate redundancy statistic: A Monte Carlo study. Multivariate Behavioral Research 10(2): 233-244.

Namieśnik J, Jamrógiewicz Z (1998) Fizykochemiczne metody kontroli zanieczyszczeń środowiska. WNT, Warszawa.

Orlova KN, Pietkova IR, Borovikov IF (2015) Analysis of air pollution from industrial plants by lichen indication on example of small town. IOP Conference Series: Materials Science and Engineering 91: 012072. https://doi.org/10.1088/1757-899X/91/1/012072

Parzych A, Zduńczyk A, Astel A (2016) Epiphytic lichens as bioindicators of air pollution by heavy metals in an urban area (northern Poland). Journal of Elementology 21(3): 781-795. https://doi.org/10.5601/jelem.2016.21.1.861

Poikolainen J, Kuusinen M, Mikkola K (2000) Changes in Lichen Abundance and Index of Atmospheric Purity During 1985-1995. In: Mälkönen E (ed.), Forest condition in a changing environment: the Finnish case. Forestry Sciences, Springer, Dordrecht. pp 173-178.

Ranta P (2001) Changes in urban lichen diversity after a fall in sulphur dioxide levels in the city of Tampere, SW Finland. Annales Botanici Fennici 38(4): 295-304. https://www.jstor.org/stable/23726705

Salemaa M, Derome J, Helmisaari H, et al. (2004) Element accumulation in boreal bryophytes, lichens and vascular plants exposed to heavy metal and sulfur deposition in Finland. Science of the Total Environment 324: 141-60. https://doi.org/10.1016/j.scitotenv.2003.10.025

Sales K, Kerr L, Gardner J (2016) Factors influencing epiphytic moss and lichen distribution within Killarney National Park. Bioscience Horizons: The International Journal of Student Research 9: hzwoo8.

https://doi.org/10.1093/biohorizons/hzwoo8

Seaward MRD (2015) Lichens as agents of biodeterioration. In: Upreti D, Divakar P, Shukla V, Bajpai R (eds.), Recent Advances in Lichenology. Springer, New Delhi, pp. 189-211. https://doi.org/10.1007/978-81-322-2181-4_9

Sett R, Kundu M (2016) Epiphytic lichens - their usefulness as bioindicators of air pollution. DJRES 3(3): 017-024.

Sevgi E, Yllmaz OY, Çobanoğlu Özyiğitoğlu G, et al. (2019) Factors influencing epiphytic lichen species distribution in a managed Mediterranean Pinus nigra Arnold Forest. Diversity 11: 59. https://doi.org/10.3390/d11040059

Smith CW, Aptroot A, Coppins BJ, et al. (eds.) (2009) The lichens of Great Britain and Ireland. British Lichen Society, London. p1047.

Sujetoviene G (2015) Monitoring Lichen as Indicators of Atmospheric Quality. In: Upreti D, Divakar P, Shukla V, Bajpai R (eds.), Recent Advances in Lichenology. Vol. 1. Modern Methods and Approaches in Biomonitoring and Bioprospection. Springer, New Delhi. pp 87-118.

https://doi.org/10.1007/978-81-322-2181-4_4

Tanona M, Czarnota P, Ortyl B (2017) Wykorzystanie transplantowanych plech Hypogymnia physodes (L.) Nyl. w ocenie zanieczyszczenia miasta Rzeszowa. Polish Journal for Sustainable Development 21(1): 69-80.

https://doi.org/10.15584/pjsd.2017.21.1.8

Tretiach M, Piccotto M, Barufo L (2007) Effects of ambient $\mathrm{NO}_{\mathrm{x}}$ on chlorophyll a fluorescence in transplanted Flavoparmelia caperata (lichen). Environmental Science and Technology 41: 2978-2984.

Van Dobben HF, Wolterbeek HTh, Wamelink GWW, et al. (2001) Relationship between epiphytic lichens, trace elements and gaseous atmospheric pollutants. Environmental Pollution 112(2): 163-169. https://doi.org/10.1016/So269-7491(oo)o0121-4

Vondrák J, Urbanavichus G, Palice Z, et al. (2019) The epiphytic lichen biota of Caucasian virgin forests: a comparator for European conservation. Biodiversity Conservation 28: 3257-3276. https://doi.org/10.1007/s10531-019-01818-4

Węgrzyn M, Wietrzyk-Pełka P, Lisowska M, et al. (2016) What influences heavy metals accumulation in arctic lichen Cetrariella delisei in Svalbard? Polar Science 10(4): 532-540. https://doi.org/10.1016/j.polar.2016.10.002

Will-Wolf S (2010) Analyzing lichen indicator data in the Forest Inventory and Analysis Program. General Technical Reports PNW-GTR-818. Portland, OR: U.S. Department of Agriculture, Forest Service, Pacific Northwest Research Station. https://doi.org/10.2737/PNW-GTR-818

Will-Wolf S, Jovan S, Neitlich P, et al. (2015) Lichen-based indices to quantify responses to climate and air pollution across northeastern U.S.A. The Bryologist 118(1): 59-82. https://doi.org/10.1639/0007-2745-118.1.059

Wirth V (1995) Die Flechten Baden-Württembergs. Teil 1 \& 2. E. Ulmer, Stuttgart.

Wirth V (2010) Ökologische Zeigerwerte von Flechten - erweiterte und aktualisierte Fassung. Herzogia 23: 229-248.

$\mathrm{Xu}$ LS, Mu GJ, Ren X, et al. (2016) Oasis microclimate effect on the dust deposition in Cele Oasis at southern Tarim Basin, China. Arabian Journal of Geoscience 9(4): 1-7. https://doi.org/10.1007/s12517-016-2312-2 